\title{
Is European Monetary Policy Appropriate \\ for the EMU Member Countries? \\ A Counterfactual Analysis
}

\author{
Bernd Hayo \\ (Philipps-University Marburg and ZEI, University of Bonn)
}

\begin{abstract}
This paper analyses whether interest rate paths in the EMU member countries would have been different if the previous national central banks had not handed over monetary policy to the ECB. Using estimates of monetary policy reaction functions over the last 20 years before the formation of EMU, we derive long-run rules the relate interest rate setting to the expected one-year ahead inflation rate and the current output gap. These Taylor rules allow to derive long-run target rates which are employed in the simulation of counterfactual interest rate paths over the time period January 1999 to December 2004 and then compared to actual short-term interest rates in the euro area. It is found that for almost all EMU member countries euro area interest rates tend to be below the national target interest rates, even after explicitly accounting for a lower real interest rate in the EMU period, with Germany being the only exception.
\end{abstract}

JEL: $\quad$ E5

Keywords: Taylor rule, monetary policy, ECB, European Monetary Union

\section{Correspondence:}

* Faculty of Business Administration and Economics (FB 02), Philipps-University Marburg, Universitaetsstr. 24, D-35037 Marburg, Germany. Phone: +49-(0)6421-28-23091, Fax: +49-(0)6421-28-23088, Email: hayo@wiwi.uni-marburg.de

** Center for European Integration Studies, University of Bonn, Walter-Flex-Str. 3, D53113 Bonn, Germany 


\section{Introduction}

The creation of the European Monetary Union (EMU) is the most important event in monetary economics in the last decade. It led to at least two potentially important changes with respect to the setting of short-term interest rates in the EMU member countries. First, the European Central Bank (ECB) bases its monetary policy decisions on aggregate developments in the euro area, which may conceal diverse developments at the national level. Second, the weights on inflation and output in the ECB Taylor rule may deviate from those that were a good description of national interest rates in the pre-EMU phase. The core question of this paper is how appropriate the actual ECB interest rate setting is for each of the member countries compared to a situation where national central banks were still responsible for monetary policy. This analysis may also yield some insights into the question of whether monetary policy can be blamed for the low GDP growth rate in a number of EMU member countries, e.g. Germany or Italy.

In this study we interpret short-term interest rates as the prime indicators of monetary policy. Estimated monetary policy reaction functions in the form of Taylor-rules are often used as concise descriptions of the monetary policy stance. They explain how deviations of output from potential output and inflation from target affect the level of interest rates. To answer the above research question, we compare the actual short-term interest rate path in the euro area with simulated interest rate path for the member countries in a counterfactual scenario.

The analysis should enable us to better understand how appropriate the centrally conducted monetary policy is for the respective member countries. If it turned out that the counterfactual national interest rate paths were relatively similar to the actual interest rate paths resulting from European monetary policy decisions, the cost of EMU from centralising monetary policy should be rather small. It would also be difficult to blame the ECB for contributing to the poor growth performance. On the other hand, if we found noteworthy deviations in the interest rates paths for at least some economies, this might raise concerns about the net benefits these countries can expect from EMU membership.

The plan of the paper is as follows. Section 2 discusses the empirical approach and some specification issues. Section 3 presents and discusses the empirical results of the Taylor rule estimations. In section 4 we compare the money market rate in the euro area with counterfactual target rates based on the Taylor rule estimates from the previous section. Section 5 summarises the main points and concludes. 


\section{Empirical Set up and Econometric Methodology}

It has become common to operationalise monetary policy actions by a short-term interest rate. Not only is this variable easy to obtain, setting interest rates is perceived as the common practice of central banks (Borio 1997). John Taylor's (1993) attempt to describe interest rate setting in terms of a monetary policy reaction function has been widely adopted. In such a socalled "Taylor rule", the short-term nominal interest rate, representing the central bank's monetary policy instrument, responds to deviations of inflation and output from their target levels.

In order to address the questions raised above we estimate Taylor rules for most of the member countries of EMU using monthly data from the formation of the European Monetary System (EMS) onwards (1979:4 - 1998:12). The central bank's target level for short-term nominal interest rates is modelled as a function of the deviation of current output from its trend and of the expected deviation of one year ahead inflation from its (constant) target:

$$
\begin{aligned}
\mathrm{i}_{\mathrm{t}}^{\mathrm{T}}=\mathrm{r}^{*}+\pi^{*}+\beta\left(\pi_{\mathrm{t}+12}-\pi^{*}\right)+\gamma \mathrm{y}_{\mathrm{t}}, \\
\text { with: } \quad \mathrm{i}^{\mathrm{T}}=\text { target nominal interest rate, } \\
\mathrm{r}^{*}=\text { long-run real interest rate, } \\
\mathrm{y}=\text { output gap, } \\
\pi=\text { inflation rate, } \\
\pi^{*}=\text { target inflation rate, } \\
\beta=\text { inflation weight in the target interest rate, } \\
\gamma=\text { output weight in the target interest rate. }
\end{aligned}
$$

The long-run level of the nominal interest rate when inflation is equal to its long-run target level and the output gap is zero is given by $\mathrm{r}^{*}+\pi^{*}$. The constant of the target interest rate is given by:

$$
\alpha=\mathrm{r}^{*}+(1-\beta) \pi^{*} .
$$

with: $\alpha=$ constant of the target interest rate,

Finally, we allow for interest rate smoothing by including a lagged interest rate term in the Taylor rule specification. Castelnuovo (2003) argues that the explicit modelling of a lagged interest rate term is preferable to an autoregressive errors specification. In the 
empirical estimations of the Taylor rules, we adopt the forward-looking specification first proposed by Clarida et al. (1998), which leads to the following equation:

$$
\begin{aligned}
i_{t}=\rho i_{t-1} & +(1-\rho) \alpha+(1-\rho) \beta \pi_{t+12}+(1-\rho) \gamma y_{t}+\varepsilon_{t}, \\
\text { with: } \quad i & =\text { nominal short-term interest rate, } \\
& =\text { degree of interest rates smoothing, } \\
\varepsilon & =\text { error term. }
\end{aligned}
$$

The presence of interest rate smoothing implies that there is partial adjustment of nominal interest rates to their target level, with a fraction of 1- $\rho$ of the difference between the target rate and last period's rate being eliminated each period.

A major problem when working with forward-looking and contemporaneous variables is that they may be correlated with the error term, leading to biased estimates of the coefficients of interest. Therefore, these variables must be instrumented. In addition, the error term may experience non-normality, autocorrelation and heteroscedasticity, causing problems with respect to statistical estimation and inference. It is now common to use the General Method of Moments (GMM) estimator, as it accounts for endogeneity biases as well as non-spherical errors. However, while the GMM estimator possesses excellent asymptotic properties, it may perform poorly in small samples (see the special issue of the Journal of Economics and Business Statistics 1996).

A potentially important general estimation problem in this context is the choice of instruments. Good instruments are variables that are uncorrelated with the error term and highly correlated with the variable that needs to be instrumented. Thus, good instruments should on the one hand fulfil the orthogonality conditions between regressors and error term. Typically, this assumption is investigated using a test of the validity of over-identifying restrictions when there are more instruments than estimated coefficients (Davidson and McKinnon 1993). However, it should be noted that the test of over-identifying restrictions in fact tests the joint hypotheses that the instruments are orthogonal to the error term and that the estimated model is correctly specified. Moreover, working with time-series data, it is easy to find instruments that pass this test. On the other hand, good instruments should be highly correlated with the instrumented variable. This aspect is almost never reported or even checked in applied empirical work, in spite of the fact that recent research shows that the use of weak instruments, i.e. instruments that do not contribute much to explaining the instrumented variable, can lead to substantial biases in both estimators and test statistics even 
in large samples (Hahn and Hausman 2003, Stock et al. 2002). Stock and Yogo (2003) propose a test for weak instruments based on the F-test value of the first stage regression in a two-stage least squares procedure.

However, one still has to solve the practical problem of choosing among a large number of potential instruments the ones that should be included. This instrument selection problem follows Hayo and Hofmann (2006) by applying a recently developed automatic model selection algorithm called GETS (see Hendry and Krolzig 1999). GETS starts from a general model and removes redundant instruments. While doing so, it searches all possible paths of the testing-down process and reports the most parsimonious model that does not violate a reduction test. Thus, the strongest instruments will be selected from a given choice of variables and their lags. This does not remove all arbitrariness, as, for instance, the researcher still needs to choose the potential instrumental variables and their maximum lag length, but it appears to be superior to the ad hoc methods typically employed in empirical research.

\section{Empirical Estimation of National Monetary Policy Reaction Functions}

To prepare the ground for the counterfactual simulations, we need to estimate the national Taylor rules before the start of EMU. The data utilised in the analysis are: money market rate for the interest rate, seasonally adjusted industrial production for output and annualised rate of change in the seasonally adjusted CPI for inflation. ${ }^{1}$ As instruments, we use up to six lagged values of the interest rate, the inflation rate, the output gap, the growth rate of the effective real exchange rate, the growth rate of the oil price index in the local currency, and the monthly growth rate of narrow money. Following Clarida et al. (1998) the output gap has been constructed by taking the residuals of a regression of the industrial production series on a constant, a linear trend and a quadratic trend. Table 1 summarises the estimation results using the general method of moments (GMM). First, we should analyse the adequacy of the chosen instruments. As was expected, none of the instruments sets fails the J-test, the p-values of which are given in the last columns of tables 1 and 2. Applying the weak instrument test by Stock and Yogo (2003) indicates that in almost all cases we can reject at a 5\% significance level the hypothesis that the instrumental variable estimator experiences a $5 \%$ bias relative to the OLS estimator.

\footnotetext{
1 The data source are the International Financial Statistics (online access) published by the International Monetary Fund. In the case of Ireland, due to data availability, producer prices were used instead of consumer prices. Interest rates were missing in the case of France from 1986:3 to 1986:6. Values were added based on a linear adjustment between these dates.
} 
Table 1: GMM Estimates of National Monetary Policy Reaction Functions

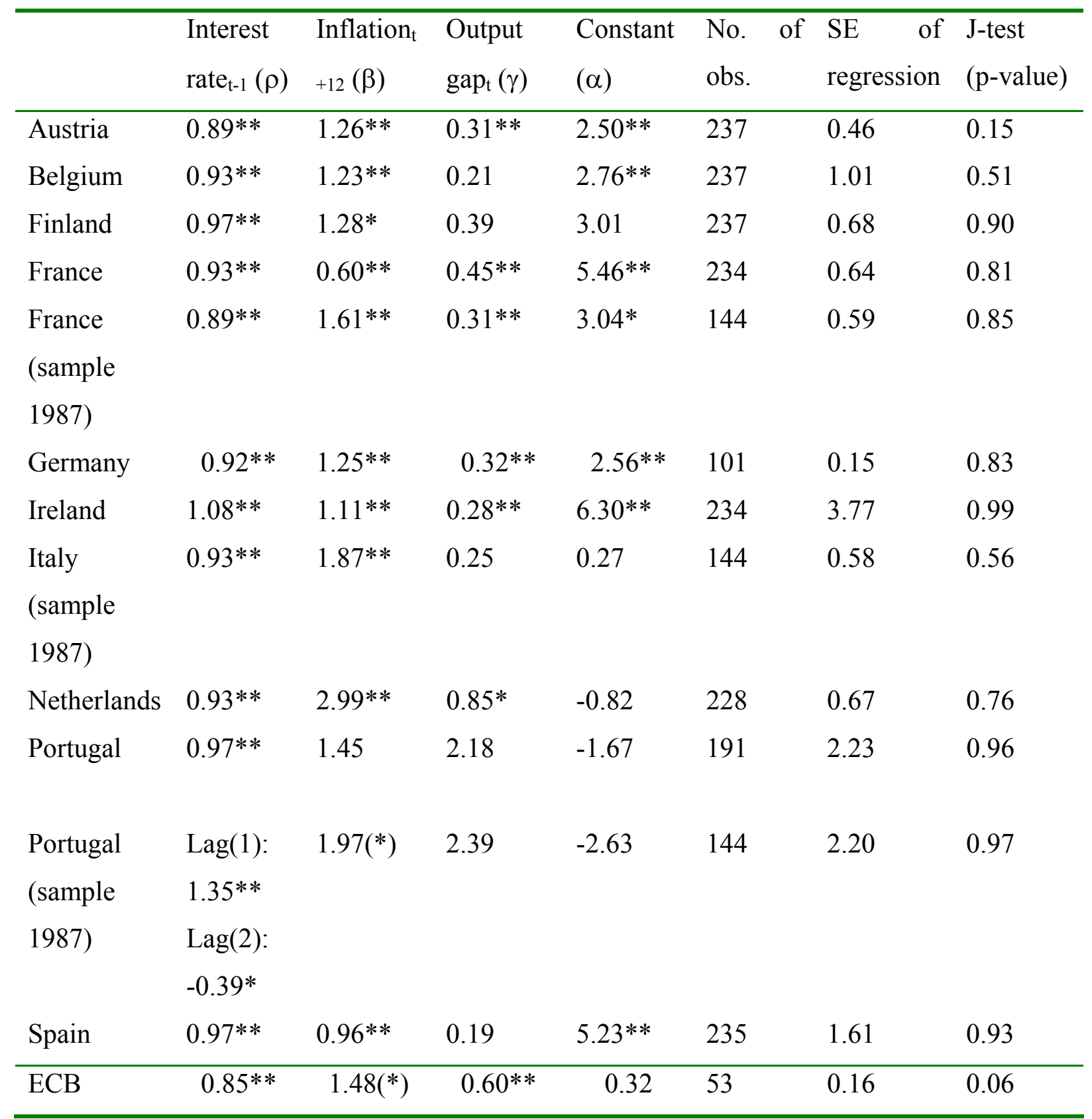

Notes: $(*), *$, and $* *$ indicate significance at a $10 \%, 5 \%$, and $1 \%$ level, respectively. Standard errors for coefficient estimates are computed using the procedure by Newey and West (1987). The estimates for the ECB and Germany are taken from Hayo and Hofmann (2006).

Exceptions are inflation in Ireland (only rejection of a 20\% bias) and the output gap in the Netherlands (only rejection of a 10\% bias). Testing the bias in the size of the instrumental variable tests at a $5 \%$ level, we can reject the hypothesis of a $10 \%$ bias in most cases. Again there are some problems, this time with inflation and output gap in Belgium (only rejection of a $15 \%$ bias), inflation in Ireland (not even rejection of a $25 \%$ bias), and the output gap in the Netherlands (rejection of a $20 \%$ bias). All in all, we should consider the instruments to be 
appropriate for our purposes but have to be aware of potential bias problems in instrumental variable estimates of the mentioned countries.

For some countries, plausible estimates over the full sample period could not be found. Alternatively, Taylor rules were estimated from January 1987 onwards, omitting the first phase of the EMS. In addition, there were missing values for some series, which also led to differences in the respective sample sizes. Lagged interest rates turn out to be highly significant, indicating that interest rate smoothing is important in all cases of our sample. For most countries coefficients on expected inflation greater than unity can be found. The reaction function in France estimated over the full sample period is the only instance where we have to reject the hypothesis that the coefficient is greater than unity, i.e. the so-called Taylor principle is not fulfilled. This principle ensures that nominal interest rate hikes imply increasing real interest rates. In Portugal the coefficient is not significantly different from zero when using the longer sample period. The point estimates of the output gap coefficients are generally larger than zero and lower than unity. In half of the cases, however, they are statistically not significantly different from zero (Belgium, Finland, Italy, Portugal, Spain). For robustness purposes, the Taylor rules were re-estimated after imposing zero restrictions on the output gaps where appropriate. It turned out that the resulting paths for the long-term target rates were similar to ones based on the unrestricted estimates and thus could be omitted. The constant term varies greatly between the countries and it can take on even negative values. Note, however, that in a number of cases it is not precisely estimated.

A number of EMU countries were formerly members of the EMS. Germany was typically perceived as performing the role of a nominal anchor and dominating the system (Wyplosz 1989; von Hagen and Fratianni 1990). To account for such an influence, we re-estimate the Taylor rules allowing for the German interest rate to enter as an additional exogenous regressor. The long-run coefficients are then computed based on the equilibrium condition: $i_{t}$ $=\mathrm{i}_{\mathrm{t}-1}=\mathrm{i}_{\mathrm{t}}$ Germany . It turns out that for some countries it is not possible to derive sensible monetary policy reaction functions within such a specification. The cases that yield reasonable estimates are summarised in Table 2.

It should be noted that the German interest rate is significant in very few countries only, namely Austria, Belgium and Ireland. $^{2}$ However, the result in Ireland is very much a reflection of the interest rate convergence occurring in the period preceding EMU.

\footnotetext{
${ }^{2}$ Clausen and Hayo (2006) estimate a small-scale macroeconomic model of Germany, France and Italy based on quarterly data that allows for a simultaneous influence of the German interest rate on the monetary policy reaction functions in the other countries. They find a significant impact at the $10 \%$ level of the German rate on the dynamic French reaction function but no significant effect in Italy.
} 
Interestingly, the German rate is not significant in the Taylor rule of the Netherlands, which kept a fixed rate to the DM since the breakdown of the Bretton-Woods system.

Table 2: GMM Estimates of National Monetary Policy Reaction Functions (with German interest rate or start of sample in 1987:1)

\begin{tabular}{|c|c|c|c|c|c|c|c|c|}
\hline & $\begin{array}{l}\text { Interest } \\
\text { rate }_{t-1} \\
(\rho)\end{array}$ & $\begin{array}{l}\text { Inflation }_{t+12} \\
(\beta)\end{array}$ & $\begin{array}{l}\text { Output } \\
\text { gap }_{t} \\
(\gamma)\end{array}$ & $\begin{array}{l}\text { German } \\
\text { interest } \\
\text { rate }\end{array}$ & $\begin{array}{l}\text { Constant } \\
(\alpha)\end{array}$ & $\begin{array}{l}\text { No. } \\
\text { of } \\
\text { obs. }\end{array}$ & $\begin{array}{l}\text { SE of } \\
\text { regression }\end{array}$ & $\begin{array}{l}\text { J-test } \\
(\mathrm{p}- \\
\text { value })\end{array}$ \\
\hline Austria & $0.63 * *$ & $1.08 *$ & $0.50 * *$ & $0.28 * *$ & $3.61 *$ & 237 & 0.43 & 0.37 \\
\hline Belgium & $0.70 * *$ & $2.24 * *$ & 0.11 & $0.22 * *$ & $2.56^{*}$ & 236 & 0.97 & 0.80 \\
\hline France & $0.93 * *$ & $0.54 * *$ & $0.43 * *$ & -0.02 & $5.17 * *$ & 234 & 0.65 & 0.88 \\
\hline Ireland & $0.66^{* *}$ & $1.29(*)$ & $1.21\left(^{*}\right)$ & $0.29 * *$ & $24.8 *$ & 222 & 2.02 & 0.99 \\
\hline $\begin{array}{l}\text { Italy } \\
\text { (sample } \\
\text { 1987) }\end{array}$ & $0.93 * *$ & $1.48 * *$ & 0.07 & -0.05 & 0.81 & 144 & 0.61 & 0.63 \\
\hline Netherlands & $0.93 * *$ & $3.89 * *$ & $-1.03 *$ & 0.02 & -2.59 & 228 & 0.67 & 0.74 \\
\hline Spain & $0.88 * *$ & $1.89(*)$ & 0.44 & 0.07 & 6.9 & 234 & 1.61 & 0.92 \\
\hline
\end{tabular}

Notes: $(*),{ }^{*}$, and $* *$ indicate significance at a $10 \%, 5 \%$, and $1 \%$ level, respectively. Standard errors for coefficient estimates are computed using the procedure by Newey and West (1987).

In the counterfactual analysis below, the long-run coefficients $\beta, \gamma$, and $\alpha$ will be used to derive target interest rates that are interpreted as indicators of how national monetary policy would have been pursued if EMU had not come about. However, there is a substantial problem related to the constant term in this analysis. The national Taylor rules contain constant terms that deviate substantially from $\alpha$ estimated for the ECB Taylor rule. We can derive the implied long-run real interest rate by re-arranging equation (2):

(4) $\mathrm{r}^{*}=\alpha-(1-\beta) \pi^{*}$.

If we assume an inflation goal of $2 \%$, the implied long-run real interest rate recovered from the Austrian Taylor rule from Table 1 is about 2\%. Assuming the same inflation goal for the ECB, we get a lower implied long-run real interest of $1.28 \%$. This difference in implied real interest rates between the two regimes may reflect lower real interest rates under the EMU regime due to the process of fiscal consolidation in the $1990 \mathrm{~s}$, but probably also due to lower levels of potential real growth in a number of EMU countries. Hence, the constant $\alpha$ 
may also have been lower under a counterfactual national monetary policy regime after 1999. For instance, in the case of Austria we get as an adjusted constant term:

$$
\alpha^{a d j}=r_{E C B}^{*}+\left(1-\beta_{i}\right) \pi^{*}=1.28+(1-1.26) 2=0.76
$$

Note that due to the large standard error of $\alpha$ in the ECB Taylor rule, the implied real interest rate is also very imprecisely measured. Furthermore, since there is (almost) a zero probability of observing a nominal interest rate very close to the real rate, $\mathrm{r}^{*}$ is not on the support of the probability distribution. For these reasons it seems advisable to look both, at the target rates based on the originally estimated constant terms and the adjusted constant terms. It turns out, however, that in all cases the target rates based on the non-adjusted constant terms are way above the interest rate prevailing in EMU. It is very unlikely that the monetary policy of the ECB is too loose for every member of EMU. Therefore, in the following graphical comparisons, we show the target rates based on the adjusted constant terms only.

Finally, it should be pointed out that there is likely going to be a difference between longrun target rates and actual interest rates. For example, figure 1 shows the target rates for the ECB together with the money market rate.

Figure 1: ECB Target Rates and EMU Money Market Rates

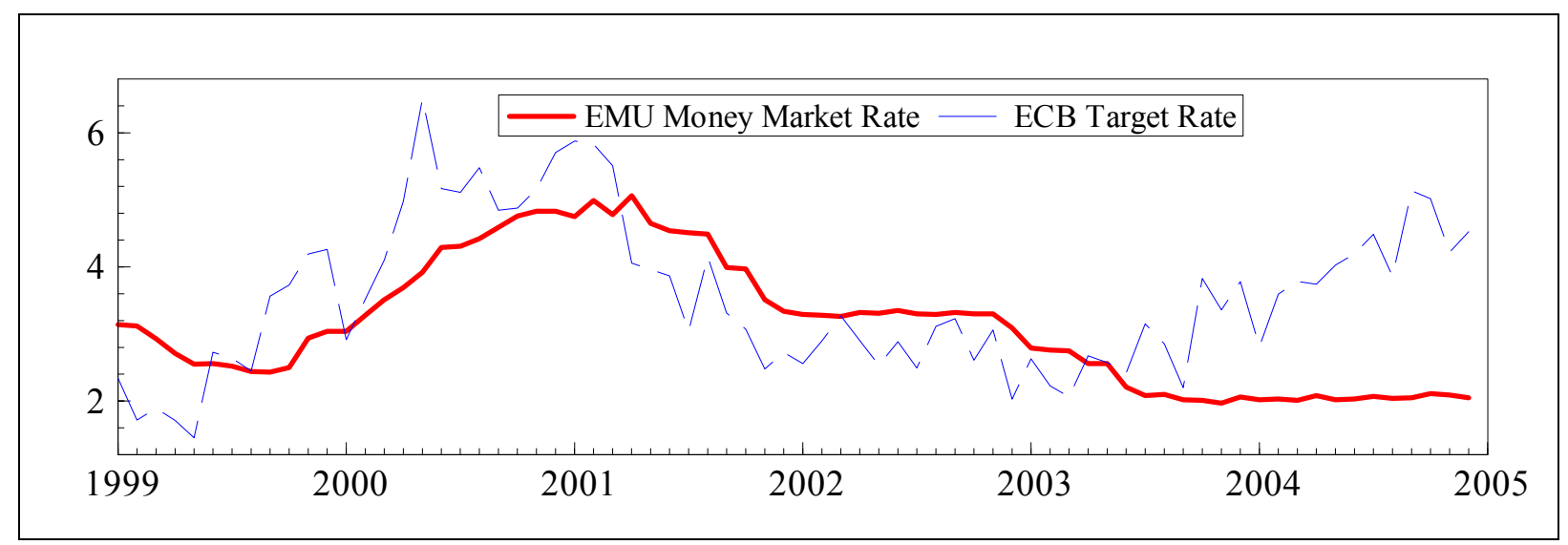

Apparently, the actual interest rates deviate from the estimated Taylor rule, particularly during the last part of the sample, where the monetary policy reaction function would recommend raising interest rates while the ECB kept rates constant. ${ }^{3}$ Hence, the comparison of counterfactual interest rate paths and actual EMU interest rates shown in following section should be interpreted with considerable carefulness.

\footnotetext{
${ }^{3}$ Note that the estimates for the ECB are taken from Hayo and Hofmann (2006), who use a sample from 1999:1 to $2004: 5$.
} 


\section{Comparing Counterfactual Interest Rate Paths}

This section compares in a counterfactual simulation analysis target rates based on national Taylor rules and national variables with the actual money market interest rates in the euro area. Figure 2 presents the simulations for Austria:

Figure 2: Austria: Target Rates and Euro Area Money Market Rate (in \%)

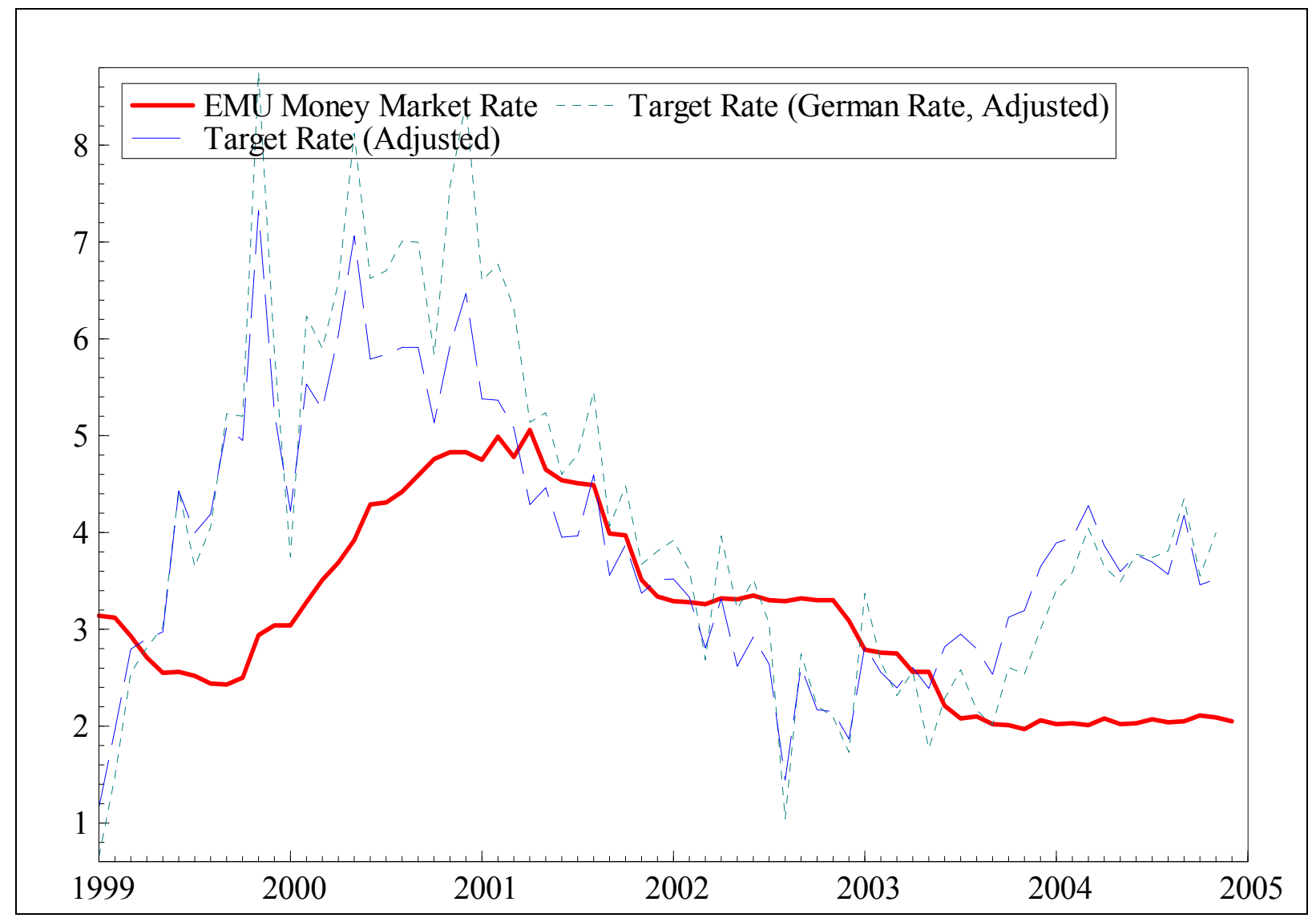

The graph suggests that for most of the time in 1999 and 2000, interest rates would have been substantially higher under a continuation of the national monetary policy regime. With an exception in the second half of 2002, actual interest rates were very close to the target rates for Austria until end of 2003. From 2004 onwards, interest rates in Austria would have risen under the hypothetical monetary policy regime. It is interesting to note that these conclusions are quite robust with respect to estimating the Taylor with or without the German interest rate.

In figure 3, the simulations for Belgium are presented. The counterfactual target rates indicate that the ECB-controlled interest rates were too low for Belgium during the course of 1999 but were relatively adequate in 2000 . 
Figure 3: Belgium: Target Rates and Euro Area Money Market Rate (in \%)

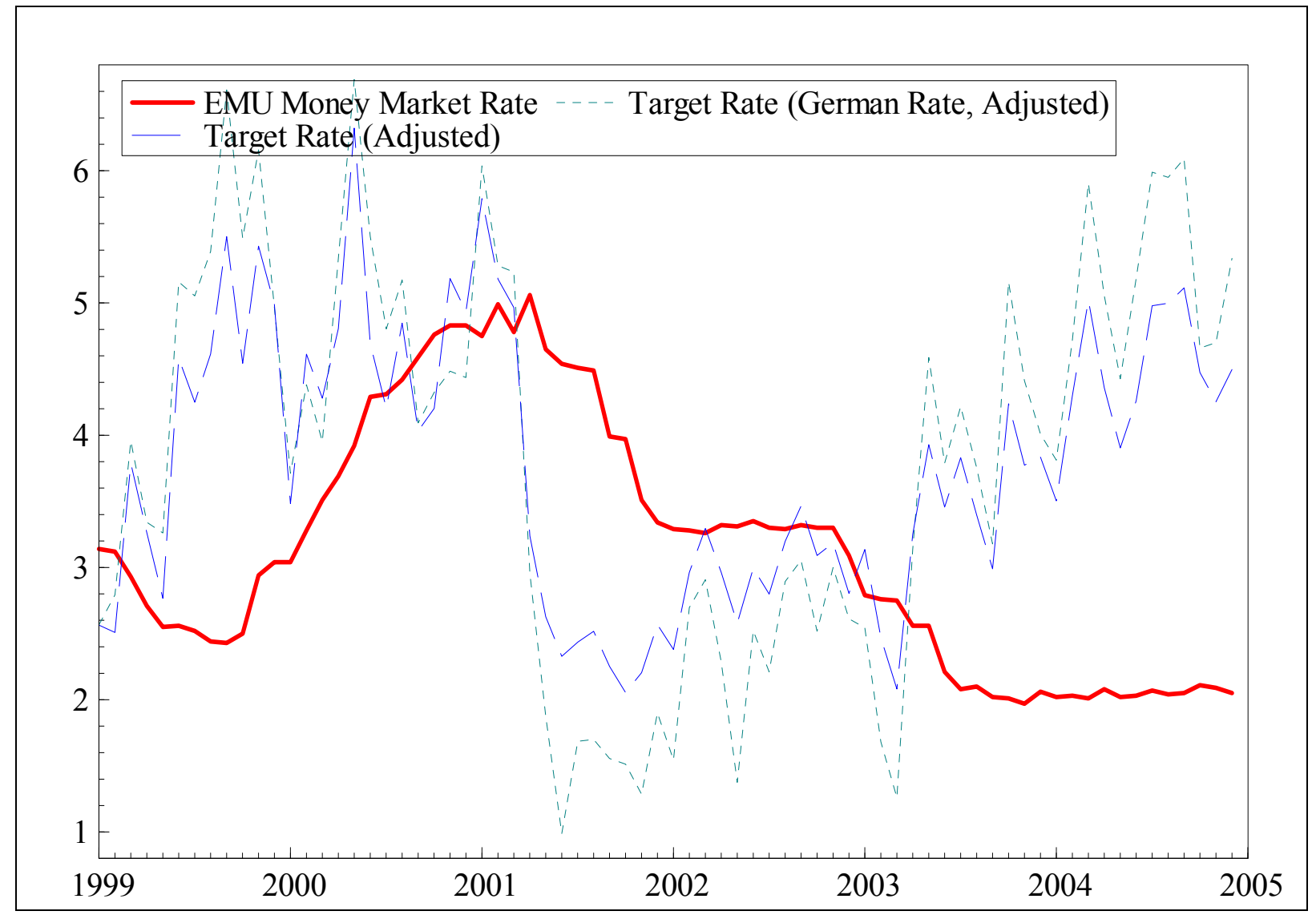

The lowering of interest rates during 2001 should have been much faster then it was actually done by the ECB. In 2002 and the first half of 2003, actual and target rates are pretty close together. From mid of 2003 onwards, the counterfactual Belgian central bank would have raised interest rates continuously, leading to a considerable gap between actual rates and target rates at the end of the sample period. Again, target rates estimated with and without a German interest rate are pretty close together most of the time.

Figure 4 shows the counterfactual scenario for Finland. Here only the Taylor rule without the German interest rate yielded reasonable estimates. The counterfactual target rates indicate that over the period start of 1999 to end of 2000 nationally determined interest rates would have been much higher than those prevailing in the euro area. In 2001 and 2002, target and actual rates are very close, while in 2003 a continuation of the Finnish monetary policy rule would have led to lower rates. For 2004, the simulations suggest that the euro area interest rate is relatively adequate for Finland. 
Figure 4: Finland: Target Rates and Euro Area Money Market Rate (in \%)

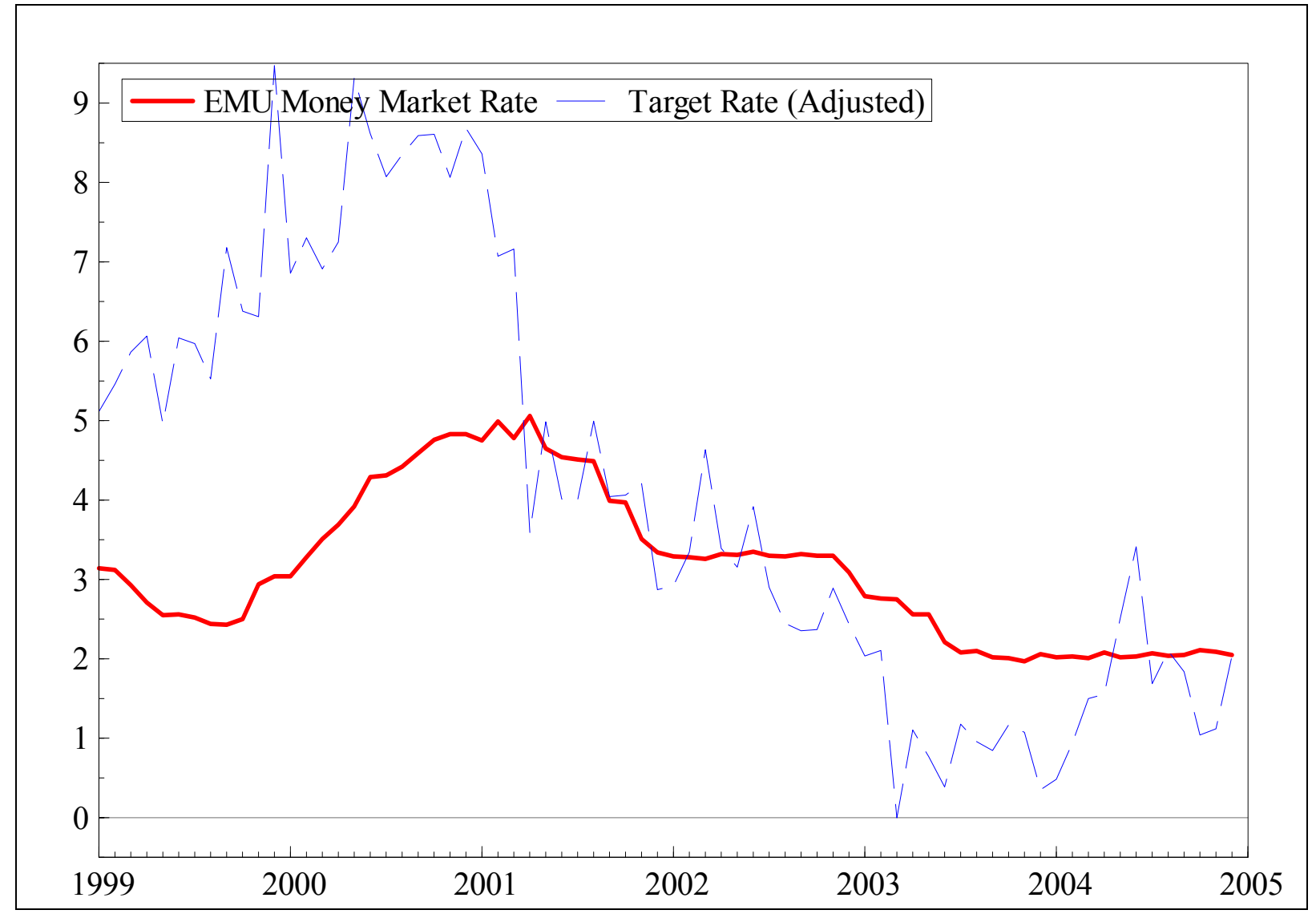

The situation in France is described in figure 5 using three alternative long-run target rates. The target rate estimated over the shorter sample period suggests that a somewhat lower rate would have come about in 2000 and 2001 but otherwise it is quite close to the other two rates that move almost synchronously. The French central bank would have set lower interest rates during the first part of 1999 but otherwise would have followed a similar course as the ECB did in practice. However, while the interest rates fell in the euro area over the course of 2003, in the counterfactual national regime target rates would have advised keeping rates stable at the level reached at the end of 2002. 
Figure 5: France: Target Rates and Euro Area Money Market Rate (in \%)

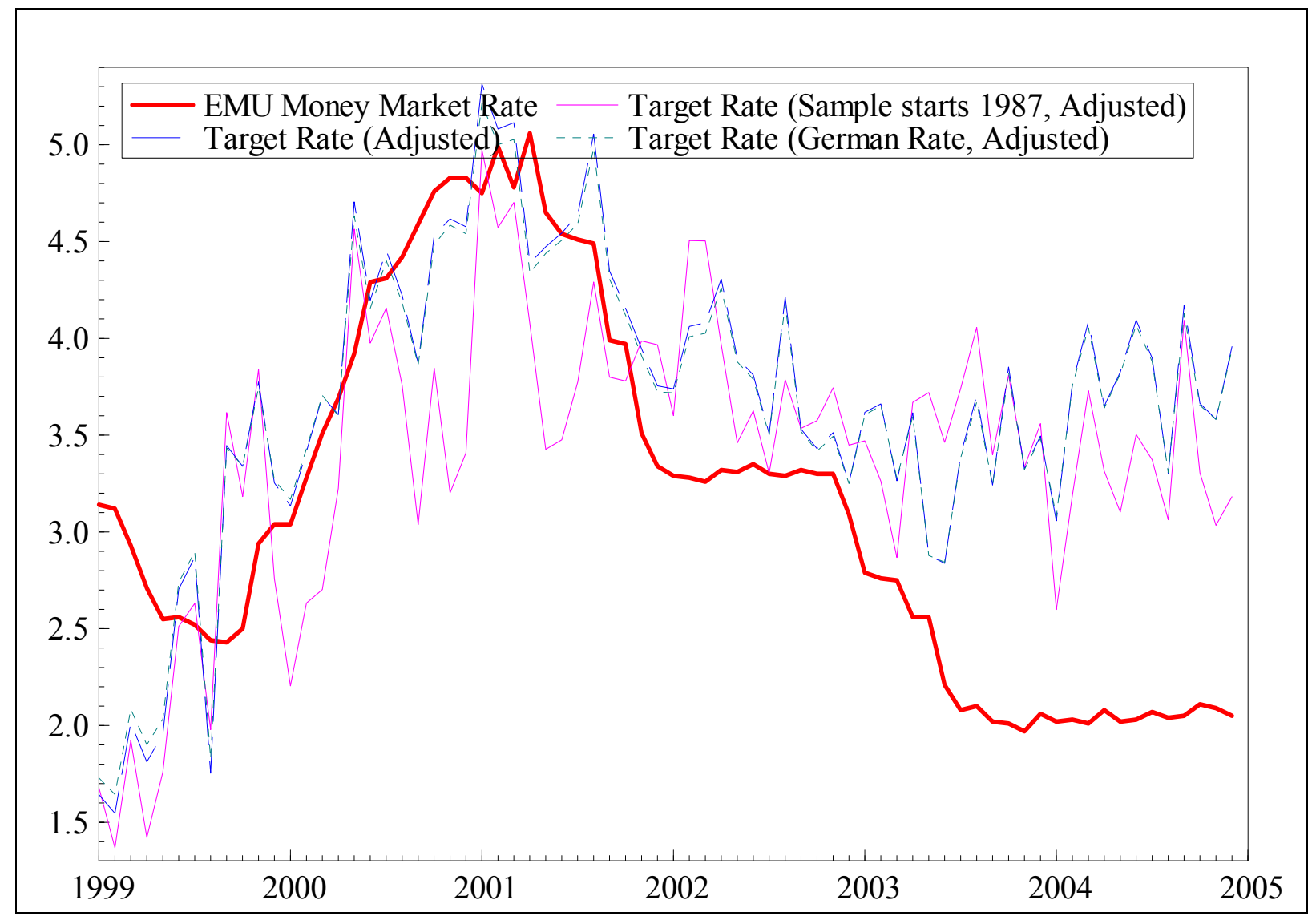

Analysing the results for the simulations in the case of Germany given in figure 6, we find that the Bundesbank would have kept interest rates somewhat higher during 1999 and clearly higher over the first half of 2000. The downswing of interest rates in 2001 would have been both, half a year earlier and much more pronounced in the counterfactual German monetary policy regime. Over the second half of 2002 and the first half of 2003 we see a convergence of rates, with actual euro area rates falling and German target rates rising. During the course of 2004 it is apparent that our counterfactual Bundesbank would have raised rates further, while the ECB held rates constant. 
Figure 6: Germany: Target Rates and Euro Area Money Market Rate (in \%)

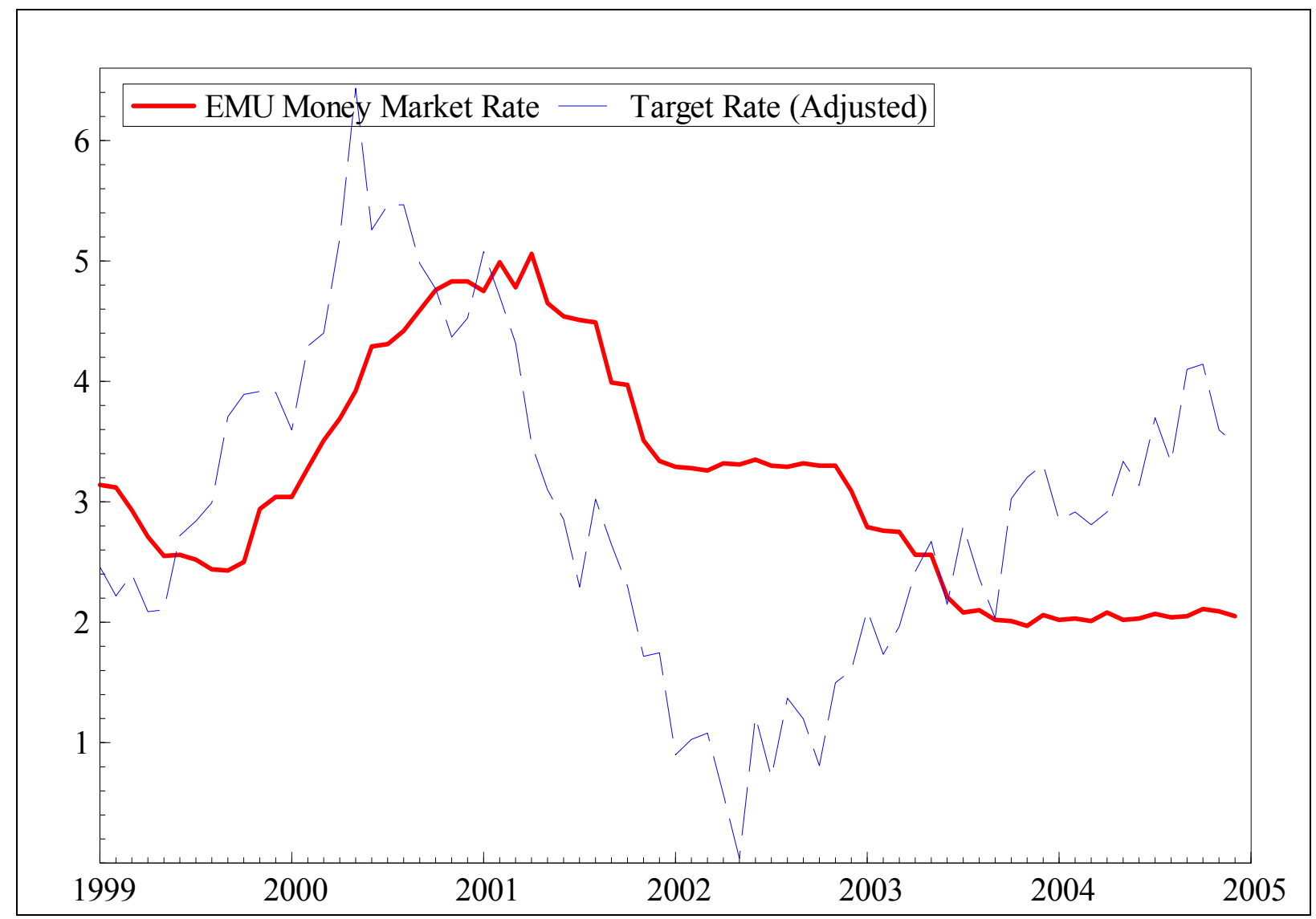

As can be seen in figure 7, there is a lot of volatility in the target rates got Ireland. This is primarily due to the fact that producer prices are used instead of consumer prices. Moreover, in the second half of 2002 target rates become negative, which is clearly not plausible. The target rates based on the estimates without the German rate indicate that in the counterfactual situation the Irish central bank would have set interest rates much higher than euro area rates in 1999. There is some convergence over the course of 2000, where on average the euro area rate is only slightly below the target rate. However, euro area rates appear to be too high in most of 2001, 2002, and 2003 for Ireland, which seems unlikely. The target rates for Ireland based on the estimates including the German interest rate are far above the actual money market rates in the euro area over the first two years. In 2001, the target rates converge closer to the actual euro area rates. In the second half of 2002, the rates become negative too for a few months. This counterfactual scenario suggests that on average the euro area rates were quite appropriate for Ireland until autumn of 2003. At the end of the present sample (which stops at the end of 2003 due to limited data availability), the target rates are already above the EMU money market rates. All in all it appears to be the case that actual rates were below the ones that would have been set under a national monetary policy regime in Ireland. 
Figure 7: Ireland: Target Rates and Euro Area Money Market Rate (in \%)

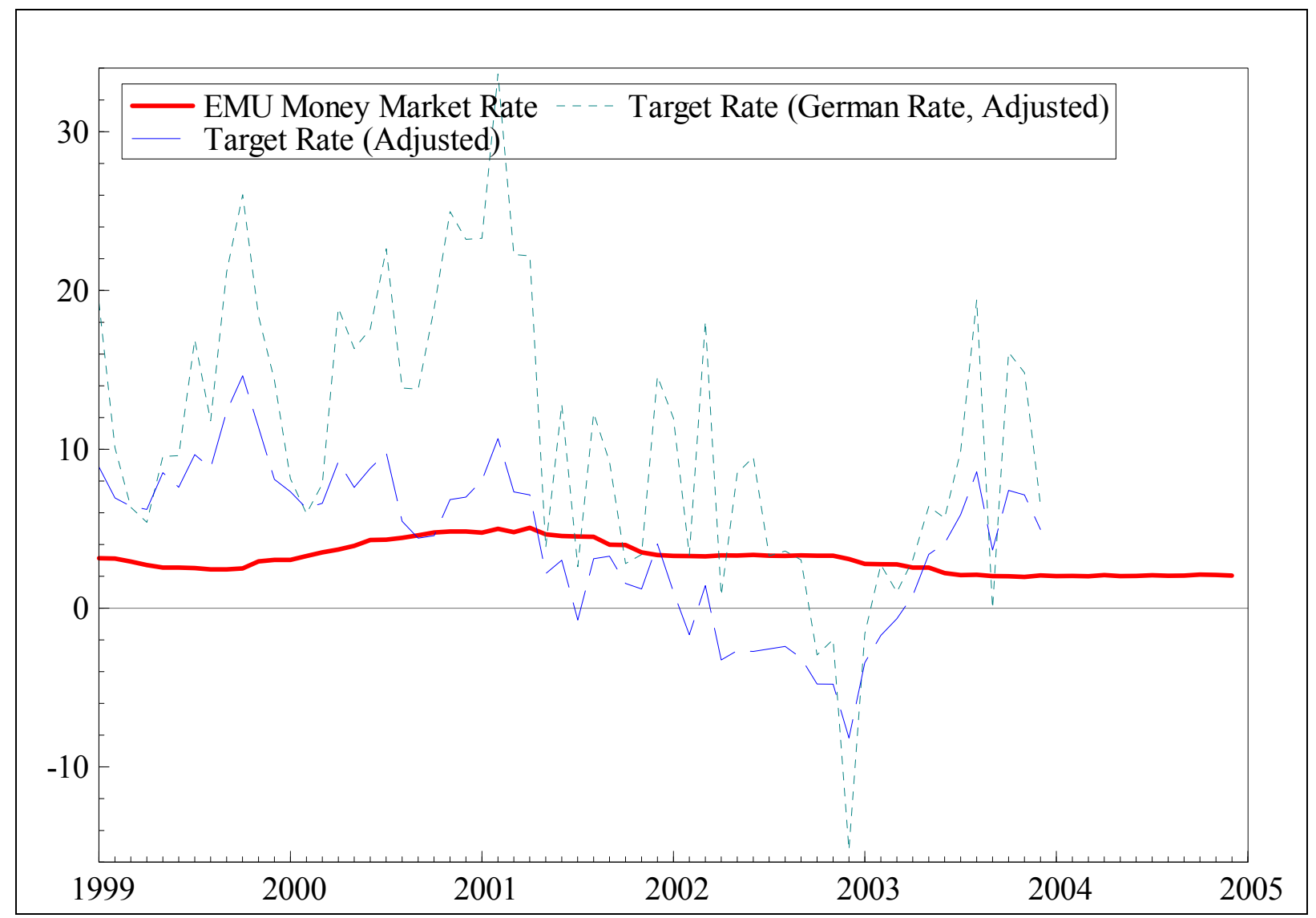

Notes: The inflation rate is based on the producer price index.

A similar conclusion but based on more plausible interest rate paths is found for Italy. Figure 8 shows that under both scenarios the target rates are above the euro area interest rates in the first two years. This conclusion changes in 2001, where at least for the interest rate path based on the estimates with the German rate the EMU rates tend to be above what a counterfactual Italian central bank would have set. For the target rate derived from the estimations without the German rate, the euro area rates appear to be slightly too high in 2001. For the remaining years, however, both interest rate scenarios suggest that national rates would have been higher, with some convergence to actual money market rates occurring at the end of the sample period. The general shape of the EMU interest rate path on the other hand is very similar to what is suggested by the target rates. 
Figure 8: Italy: Target Rates and Euro Area Money Market Rate (in \%)

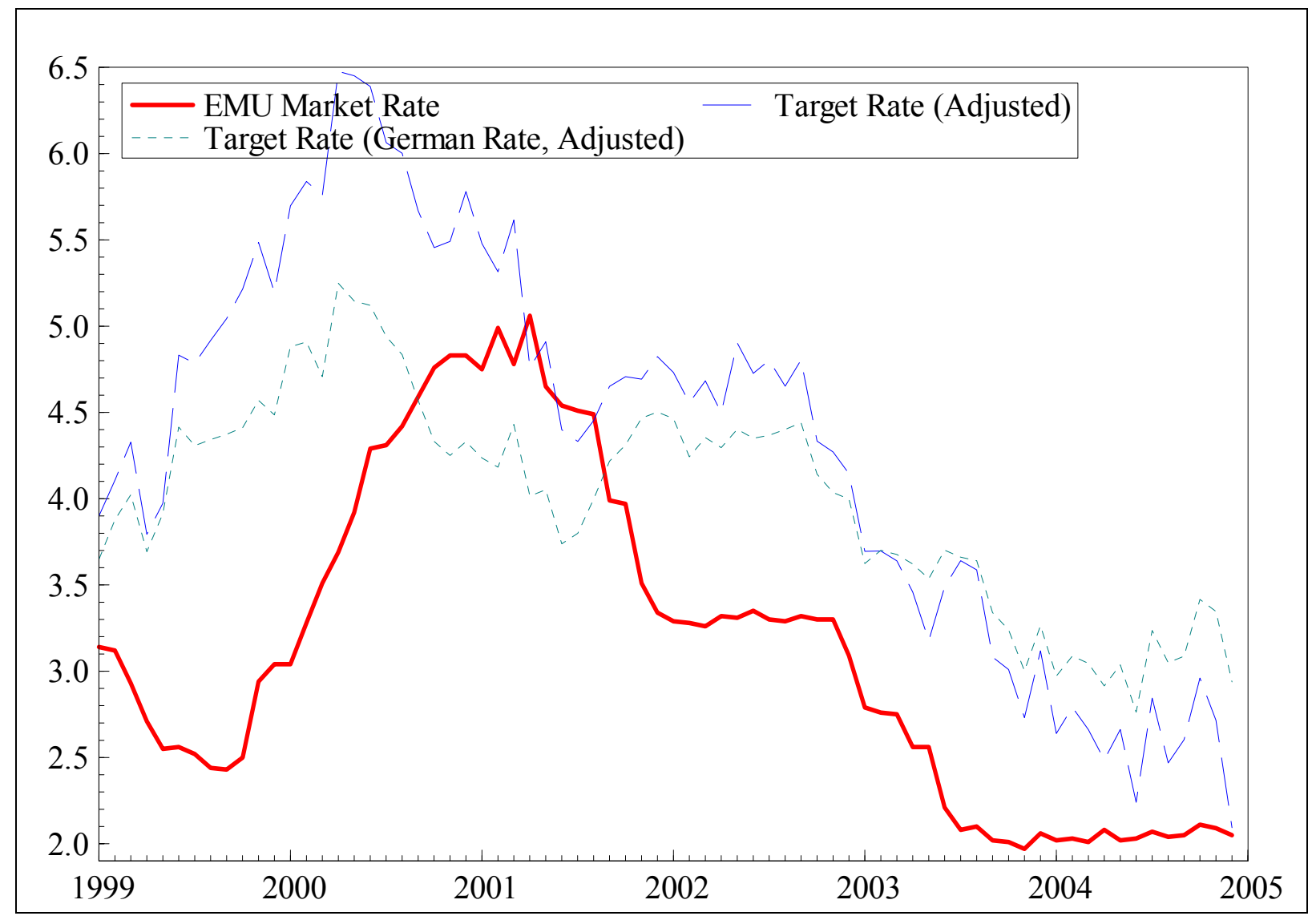

The situation is relatively straightforward in the case of the Netherlands, as can be inferred from figure 9. Most of the time, the euro area rate is quite close to the target rates. The exception is 2001, where a counterfactual Dutch central bank would have set a substantially higher interest rate. Since the target rate based on estimates without the German interest rate is more volatile and often becomes negative in 2003 and 2004 it does not appear to be very plausible. 
Figure 9: Netherlands: Target Rates and Euro Area Money Market Rate (in \%)

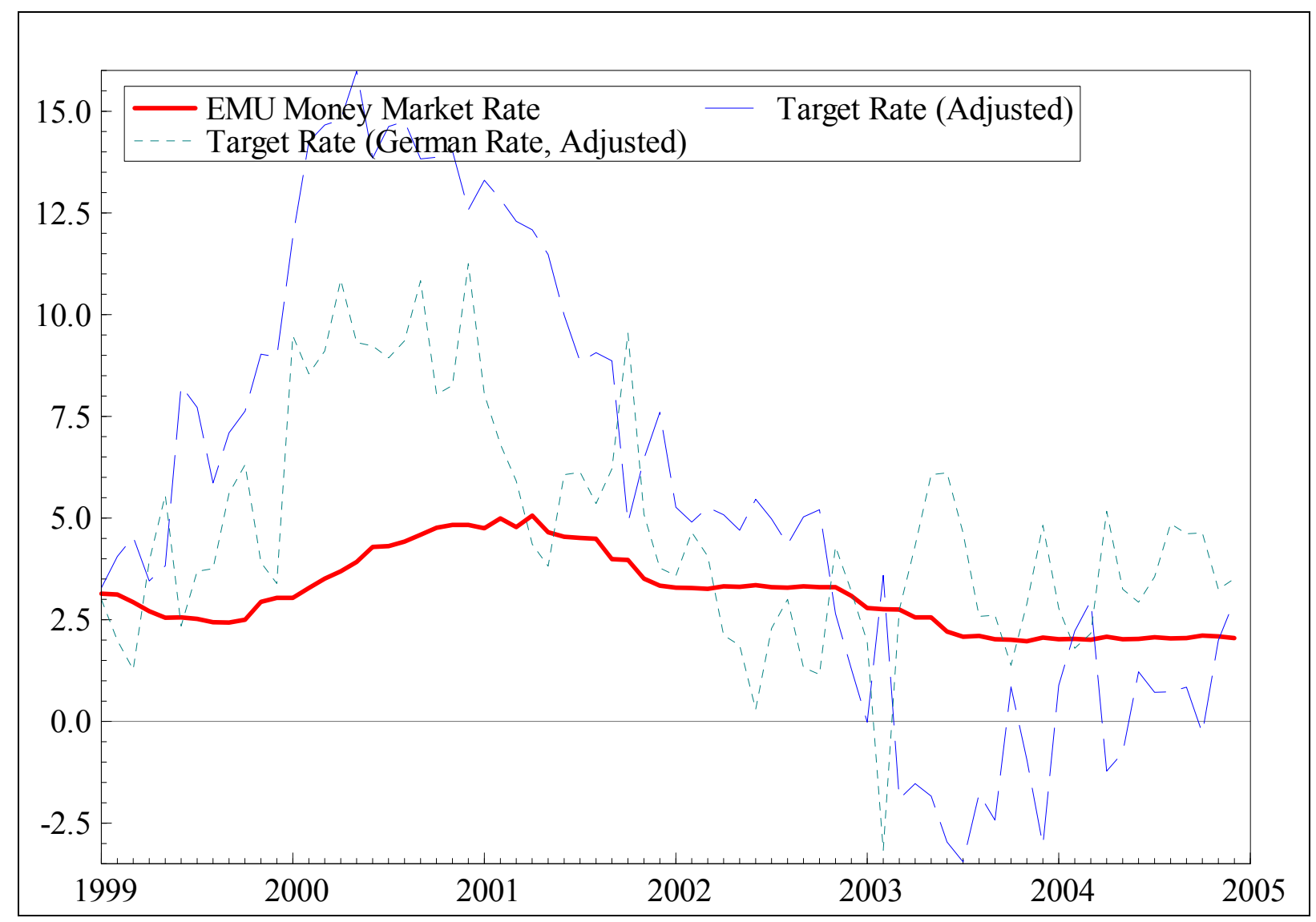

The simulations for Portugal in figure 10 do not appear to be very plausible, especially in the later part of the sample. The rates are systematically above the euro area rate until they become negative from 2004 onwards. A look at the data indicates that the substantial drop of industrial production in combination with the excessively large coefficient on the output gap is responsible for this outcome. 
Figure 10: Portugal: Target Rates and Euro Area Money Market Rate (in \%)

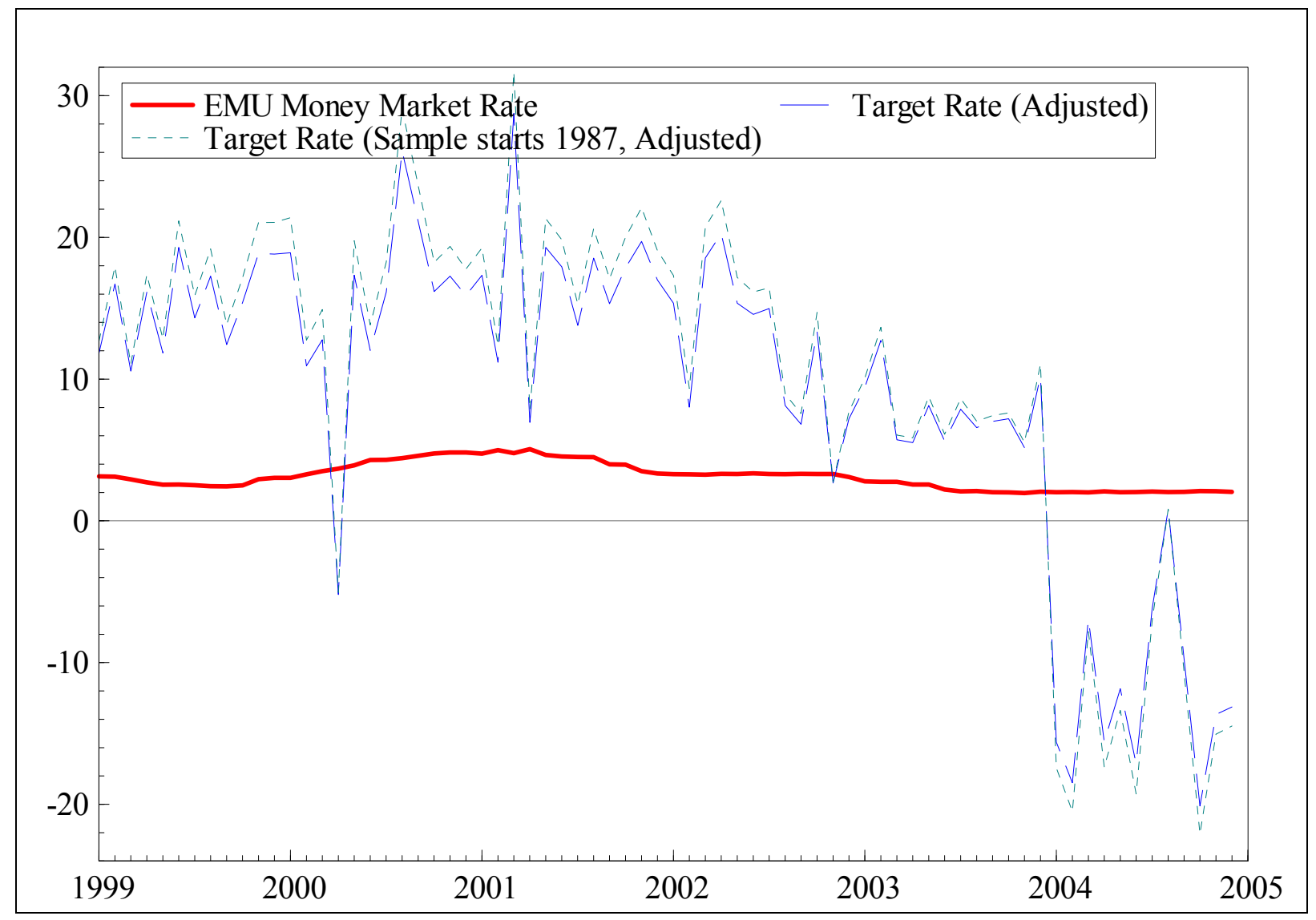

Finally, figure 11 displays the simulated interest rate paths for Spain. The target rates based on the estimates without the German interest rate are consistently above the euro area rate over the full sample. The alternative target rate indicates that euro area rates are below counterfactual Spanish rates in 1999 and the first half of 2000. In the following period until end of 2001, actual interest rates appear to be extremely close to the target rates. In 2002 the target rates are somewhat higher and the fall in actual rates from 2003 onwards stands in contrast to an increase in the target rates, resulting in a notable gap at the end of 2004. 
Figure 11: Spain: Target Rates and Euro Area Money Market Rate (in \%)

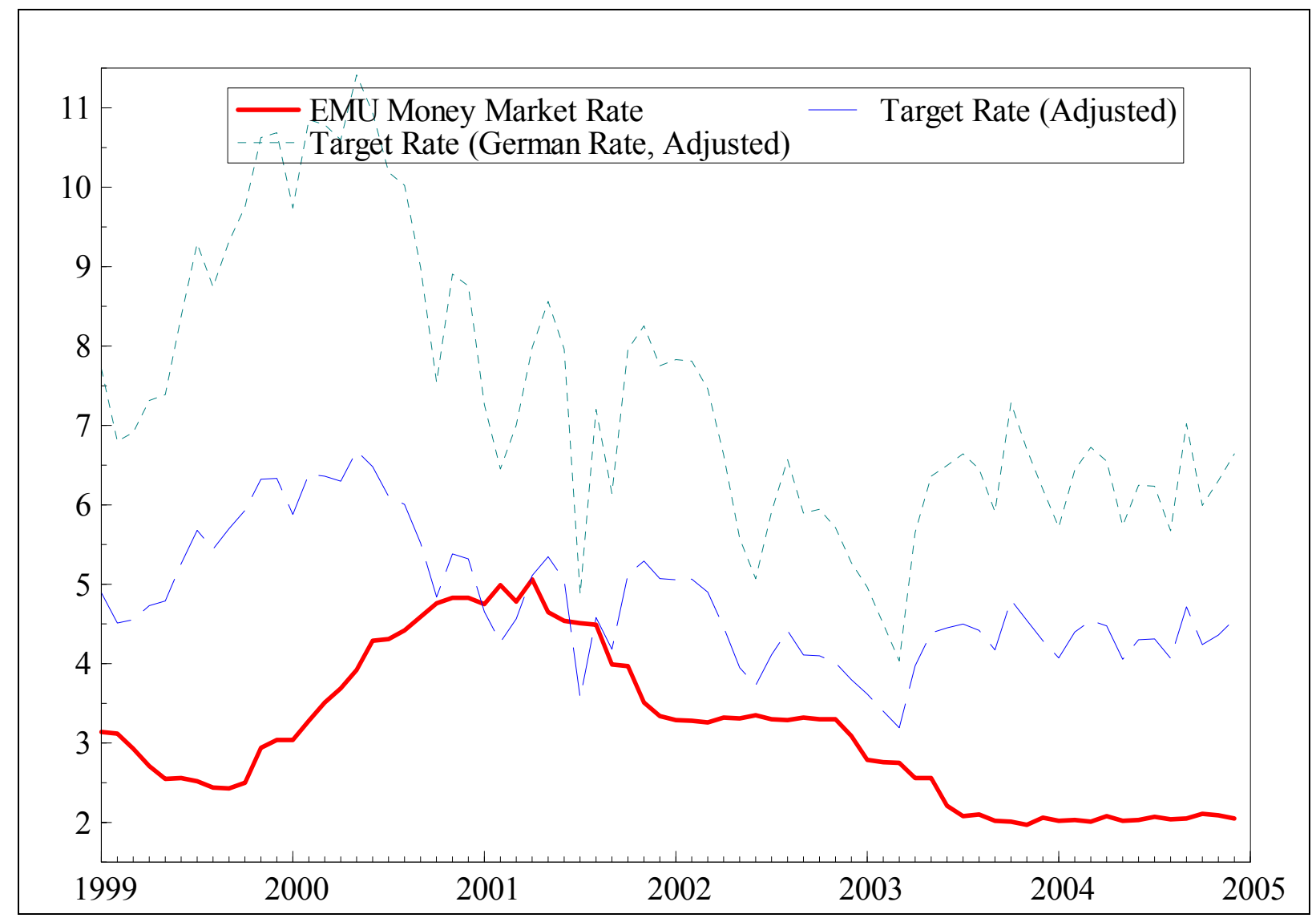

Summarising these findings in a more quantitative manner, table 3 contains the difference between the euro area interest rate and the respective target rates over countries and years for the target rate based on Taylor rule estimates without the German interest rate. Concentrating first on the country averages in the last column of the table, we find that in almost all countries actual euro area rates are below counterfactual target rates. There is one case where interest rates under the ECB regime are higher than under a continuation of its national monetary policy regime, namely Germany. This result is particularly affected by the year 2002, where counterfactual German target rates are more than 2 percentage points above the euro area rates. The biggest deviations in absolute values are computed for Portugal, followed by the Netherlands and Spain. Second, analysing the results across years, we find the average of these deviations over countries in a particular year in the second line from the bottom of the table. It becomes apparent that the largest deviations occur in the first two years, where euro area interest rates were particularly low compared our estimates of the counterfactual national monetary policy regimes. In 2001 the average deviations across countries are already smaller, in absolute terms, and they are close to zero in 2002. In 2004, the deviations turn positive but this is only due to the value from Portugal that was already characterised as not particularly plausible. As indicated above, at least in 2003 the estimates for Ireland are also a bit dubious. 
Analysing the averages for every year without Ireland and Portugal, as given in the last line of the table, yields a similar conclusion for the first two years of EMU: euro area rates are lower than what would have been set by national central banks on average. The average of differences is only slightly negative in 2001, 2002 and 2003. For 2004, however, we can see that in a number of countries target rates suggest that a tighter monetary policy would have been appropriate. This re-iterates the message from comparing ECB target rates and actual money market rates in figure 1.

Table 3: Difference between EMU Money Market Rate and Adjusted Target Rates (in percentage points)

\begin{tabular}{|c|c|c|c|c|c|c|c|}
\hline & 1999 & 2000 & 2001 & 2002 & 2003 & 2004 & Sum \\
\hline Austria & -1.2 & -1.6 & 0.1 & 0.7 & -0.5 & -1.7 & -4.3 \\
\hline Belgium & -1.3 & -0.5 & 1.2 & 0.3 & -1.0 & -2.4 & -3.8 \\
\hline Finland & -3.5 & -3.9 & -0.6 & 0.2 & 1.3 & 0.4 & -6.0 \\
\hline France & 0.2 & 0.0 & -0.2 & -0.5 & -1.1 & -1.7 & -3.2 \\
\hline Germany & -0.2 & -0.8 & 1.3 & 2.3 & -0.2 & -1.3 & 1.1 \\
\hline Ireland & -6.4 & -2.9 & 0.2 & 6.1 & -1.0 & n.a. & -4.0 \\
\hline Italy & -1.9 & -1.8 & -0.5 & -1.3 & -1.0 & -0.5 & -7.0 \\
\hline Netherlands & -3.4 & -10.0 & -5.4 & -1.2 & 3.6 & 1.0 & -15.4 \\
\hline Portugal & -12.6 & -10.8 & -12.6 & -8.8 & -5.3 & 14.3 & -35.7 \\
\hline Spain & -2.6 & -1.8 & -0.4 & -1.0 & -1.8 & -2.3 & -9.9 \\
\hline Sum & -32.8 & -34.1 & -16.9 & -3.3 & -7.0 & 5.7 & \\
\hline \multicolumn{8}{|l|}{$\begin{array}{l}\text { Sum } \\
\text { (without }\end{array}$} \\
\hline Portugal) & -13.9 & -20.4 & -4.5 & -0.5 & -0.7 & -8.5 & \\
\hline
\end{tabular}

To get a better understanding of the relationship of the differences between EMU money market rate and target rates over time and countries, we make use of a statistical clustering method. Using the nearest neighbour technique we perform a hierarchical cluster analysis. In a first step, we look for particular clusters among countries over the time period (we drop Ireland due to missing observations in 2004). The resulting dendrogram is given in figure 12. 
Figure 12: Dendrogram of Country Clusters

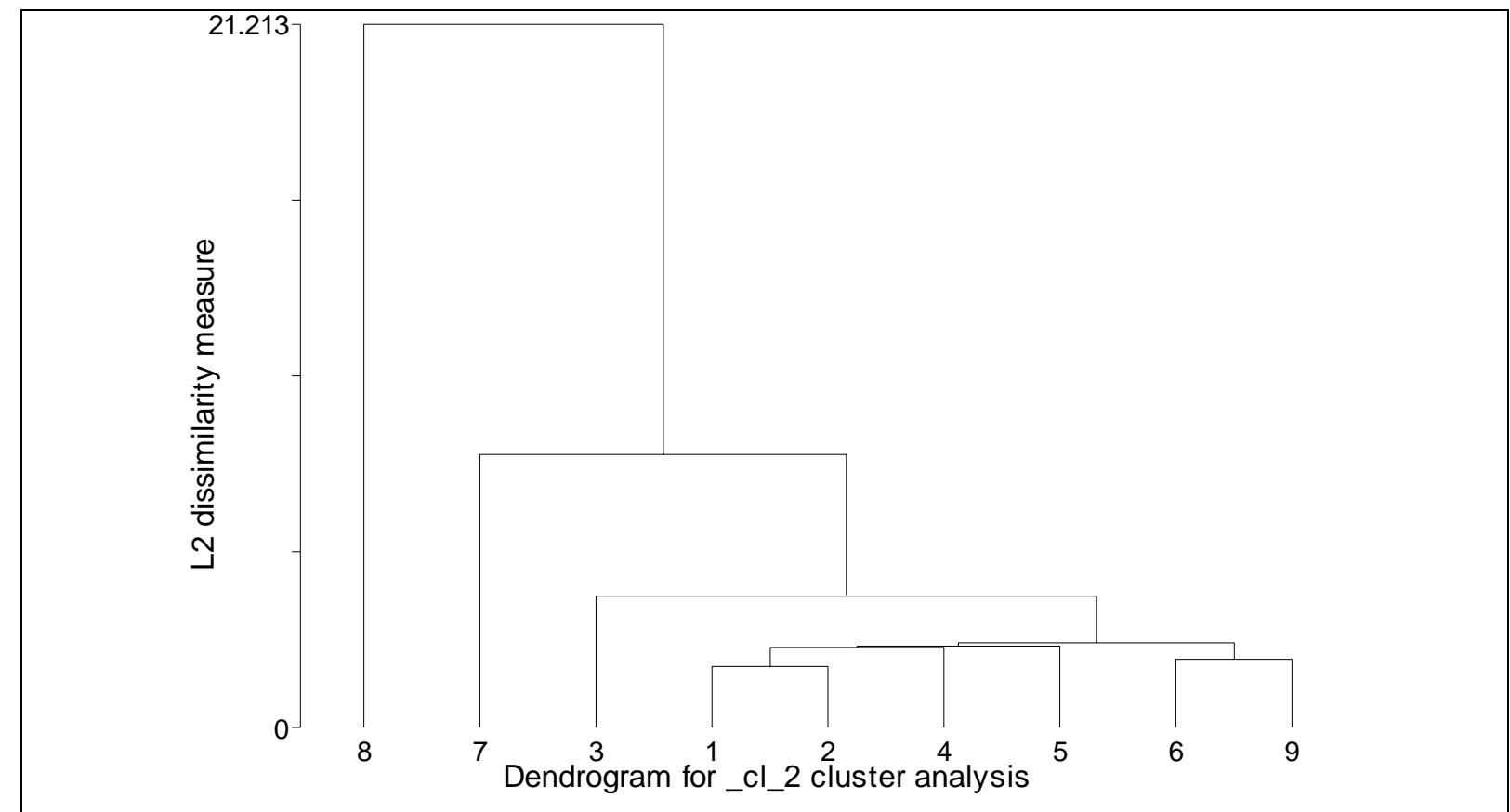

Notes: Country codes are: Austria: 1, Belgium: 2, Finland: 3, France: 4, Germany: 5, Italy: 6, Netherlands: 7, Portugal: 8, Spain: 9.

The deviations of target rates from actual interest rates in Austria, Belgium, France, and Germany are particularly similar over the time period. Italy and Spain form a relatively close cluster. The Netherlands, Finland, and specifically Portugal are the respective outliers in this respect.

Looking for particular clusters with regard to the deviations of adjusted target rate from EMU money market rate among the various years of our sample period, we get the dendrogram in figure 13. The years 1999 and 2001 form a cluster, and 2002 is still quite close. 2003 and 2000 are already different. The deviations of the adjusted target rates and the EMU money market rate are particularly different in 2004 compared to the other years. This is due to the fact that in this year the target rates of many countries tend to be well above the actual EMU money market rate. 
Figure 13: Dendrogram of Country Clusters

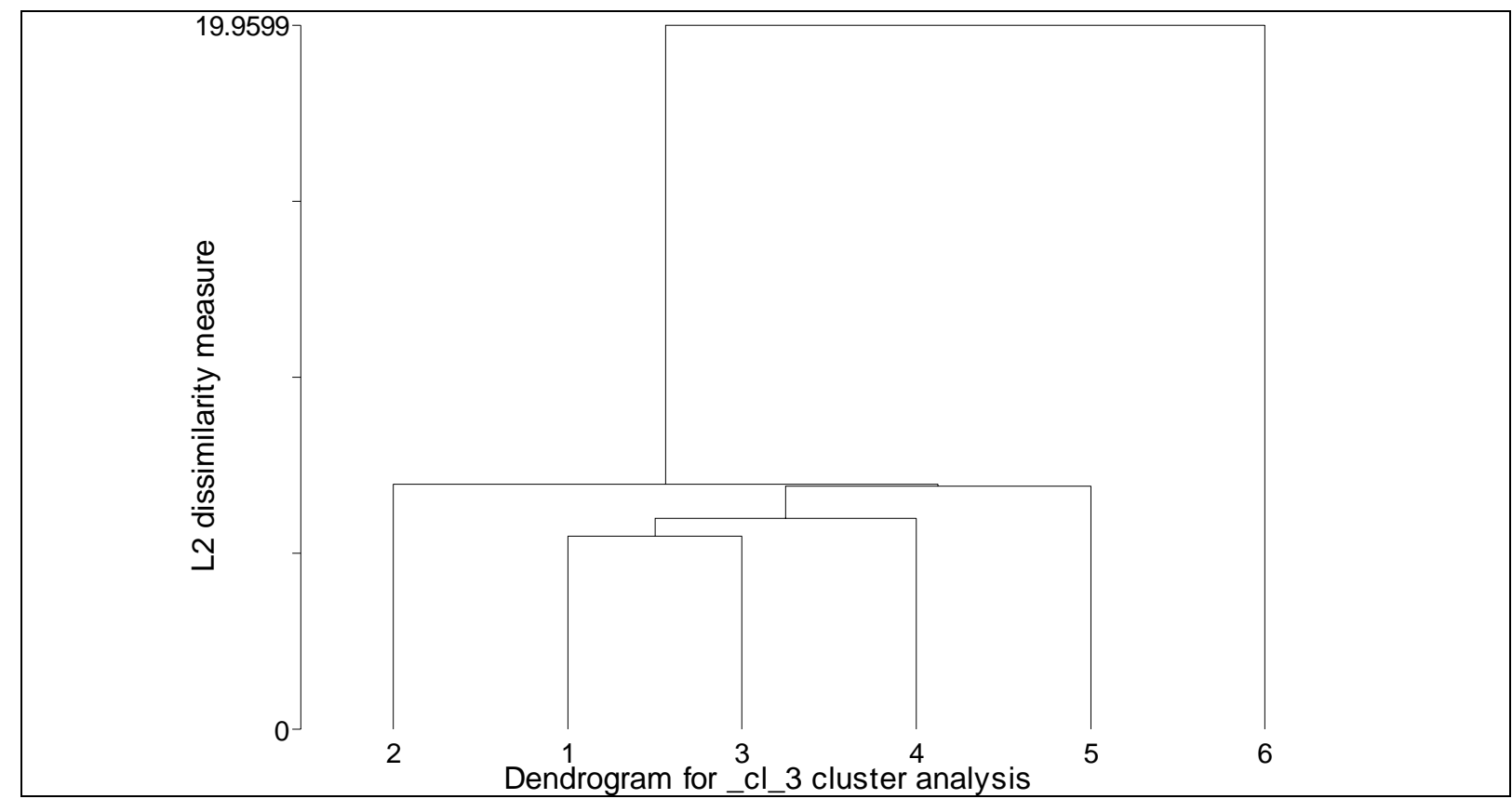

Notes: Year codes are: 1999: 1, 2000: 2, 2001: 3, 2002: 4, 2003: 5, 2004: 6

\section{Conclusions}

In this paper, we ask the question of whether interest rate paths in most of the current member countries of EMU would have been different if the previous national central banks had not given up control over monetary policy. Using estimates of monetary policy reaction functions over the last 20 years before the formation of EMU, we derive long-run Taylor rules for interest rate setting conditional on the expected one-year ahead inflation rate and the current output gap. These Taylor rules are employed in the simulation of counterfactual interest rate paths over the time period January 1999 to December 2004, which are then compared to actual short-term interest rates in the euro area.

The estimation of monetary reaction functions follows Clarida et al. (1998), where a single equation is estimated using GMM. In contrast to their approach, the present study applies a novel way of selecting instruments that avoids weak instrument biases and removes some arbitrariness in the selection process. In an alternative specification, the German shortterm interest rate is also included in the analysis to account for the membership of some countries in the EMS. It turns out that the estimations of reaction functions are sometimes not robust or even plausible, for instance, the results for Ireland and Portugal raise some questions.

With respect to the core research question, we can summarise the results as follows: Perhaps not surprisingly, most countries would have set interest rates differently to what the 
ECB did over sometimes prolonged periods of time. More specifically, ECB interest rates tend to be below the national target interest rate even after explicitly accounting for a lower real interest rate in the EMU period. This is particularly true for the years 1999 and 2000, while the actual euro area rates were more appropriate for most countries in 2001 and 2004, and on average very close to the target rates in 2002 and 2003. However, for Germany the sum of actual money market interest rates over this five year period is higher than the sum of the counterfactual national target rates. Under a counterfactual Bundesbank regime, the interest rates would have been below euro area rates in 2001 and especially in 2002. There is a cluster of country that experience relatively similar deviations of national counterfactual target rates from actual interest rates, consisting of Austria, Belgium, France, and Germany. Portugal and to a lesser extent the Netherlands tend to show a noteworthy different pattern in this respect. Clustering over years indicates that 2004 is the main outlier, particularly due to a number of national target rates suggesting an increase in interest rates, while euro area rates remain unchanged.

To conclude, almost all countries in our counterfactual simulation realise lower nominal interest rates by being members of EMU when compared to a continuation of the previous national monetary regime. In other words, if EMU had not come about, the respective countries would have experienced more restrictive monetary policies than under the ECB regime. This gain in terms of lower interest rates is a result of the high credibility imported by becoming a member of the ECB. Thus, it seems rather implausible to explain the rather disappointing GDP growth rates on average by pointing toward too high euro area interest rates.

The only exception is Germany, which may have had to cope with a somewhat higher interest rate under the ECB regime compared to a continuation of the former Bundesbank regime. The explanation of this outcome is straightforward: German interest rates were already low before the creation of EMU but due to a substantial negative output gap in some years it found the ECB rates relatively too high. So while it is difficult to argue that the common monetary policy was the cause of the dismal growth performance of the German economy, as it benefited from relatively lower rates in 1999 and 2000, it may be the case that in some years EMU exacerbated the situation to a certain extent. It is important to note that this does not prove that Germany is relatively worse off as a member of EMU, as the other countries' interest rate levels would have been higher under a continuation of the former national monetary policy regimes. The interest rate impulse generated by joining EMU has likely affected economic growth positively in these countries. The export-oriented economy 
of Germany has participated from this relative expansion of the other European economies, which helped to stabilise German output. However, within the current framework, we cannot analyse the net effect of these two diverging effects. Finally, it is interesting to note that in 2004 German target rates would have been about one percentage point higher than the actual euro area rates. Even given the increase in euro area money market interest rate at the end of 2005 to about $2.5 \%$, this suggests that for the last two years the ECB regime provides an additional stimulus for Germany too. 


\section{References}

Borio, C.E.V. (1997), The implementation of monetary policy in industrial countries: A survey, BIS Economic Papers No. 47, July.

Castelnuovo, E. (2003), Taylor rules, omitted variables, and interest rate smoothing in the US, Economics Letters 81, 55-59.

Clarida, R., J. Gali und M. Gertler (1998), Monetary policy rules in practice: Some international evidence, European Economic Review 42, 1033-1067.

Clausen, V. and B. Hayo (2006), Asymmetric monetary policy effects in EMU, Applied Economics, forthcoming.

Davidson, R. and J.G. MacKinnon (1993), Estimation and Inference in Econometrics, New York: Oxford University Press.

Hahn, J. and J. Hausman (2003), Weak instruments: diagnosis and cures in empirical econometrics, American Economic Review 93, 118-125.

Hendry, D.F. and H.-M. Krolzig (1999), Improving on 'Data mining reconsidered' by K.D. Hoover and S.J. Perez, Econometrics Journal 2, 202-219.

Hayo, B. and B. Hofmann (2006), Comparing Monetary Policy Reaction Functions: ECB versus Bundesbank, Empirical Economics, forthcoming.

Newey, W.K. and K.D. West (1987), A simple, positive semi-definite, heteroscedasticity and autocorrelation consistent covariance matrix, Econometrica 55, 703-708.

Stock, J.H. and M. Yogo (2003), Testing for weak instruments in linear IV regression, mimeo, Department of Economics, Harvard University.

Stock, J.H., J.H. Wright, and M. Yogo (2002), A survey of weak instruments and weak identification in generalized method of moments, Journal of Business \& Economic Statistics 20, 518-529.

Taylor, J. (1993), Discretion versus Policy Rules in Practice, Carnegie-Rochester Conference Series on Public Policy 39, 195-214.

Von Hagen, J. and M. Fratianni (1990), German Dominance in the EMS: Evidence from Interest Rates, Journal of International Money and Finance 9, 358-375.

Wyplosz, C.A. (1989), Asymmetry in the EMS: Intentional or Systemic?, European Economic Review 33, 310-320. 